\title{
INTERAKSI MANAJEMEN LABA DALAM PENGUNGKAPAN CORPORATE SOCIAL RESPONSIBILITY DAN KINERJA KEUANGAN SEKTOR MANUFAKTUR
}

\author{
Sri Wahyu Aji Widiatmi ${ }^{1}$ \\ 1 Universitas Mataram,email : sriwahyuajiwidiatmi@gmail.com
}

INFORMASI ARTIKEL ABSTRAK

Article history:

Dikirim : 25 Oktober 2019

Revisi pertama: 9 Desember 2019

Diterima: 11 Desember 2019

Tersedia Online : 15 Desember 2019
Tujuan penelitian ini untuk menganalisis dan mendapatkan bukti empiris tentang pengaruh pengungkapan Corporate Social Responsibility (CSR) terhadap kinerja keuangan yang dimoderasi oleh manajemen laba. Manajemen laba diproksikan dengan akrual diskresioner dan manipulasi aktivitas riil. Pengujian dilakukan pada 113 perusahaan manufaktur yang tercatat di Bursa Efek Indonesia yang melakukan pengungkapan tanggung jawab sosial perusahaan selama periode 2016-2018 dengan pendekatan purposive sampling. Data dianalisis menggunakan analisis regresi moderasi. Hasil penelitian menunjukkan bahwa pengungkapan CSR berpengaruh positif tidak signifikan terhadap kinerja keuangan. Temuan lain penelitian menunjukkan bahwa interaksi manajemen laba akrual memoderasi pengaruh pengungkapan CSR terhadap kinerja keuangan, meskipun interaksi manipulasi aktivitas riil memberikan hasil yang sebaliknya.

Kata kunci: pengungkapan CSR, ROA, manajemen laba akrual dan manipulasi aktivitas rill.

\section{ABSTRACT}

The purpose of this study to analyze and obtain empirical evidence about the effect of Corporate Social Responsibility disclosure on the financial performance moderated by earnings management. Earnings management is proxied by discretionary accrual and real activities manipulation. The test was conducted on 113 manufacturing companies listed on the Indonesian Stock Exchange which disclosed corporate social responsibility during the 2016-2018 period by using purposive sampling. Data were analyzed using moderated regression analysis. The results of this study stated that CSR disclosure had no significant effect on corporate financial performance. Other research findings show that the interaction of accrual earnings management moderates the effect of CSR disclosure on financial performance, although the interaction of real activities manipulation shows the opposite result.

Keywords: Corporate Social Responsibility disclosure, Return on Assets, discretionary accrual, real activities manipulation 


\section{Pendahuluan}

Perkembangan dunia industri manufaktur terus mengalami perkembangan setiap tahunnya, hal ini menyebabkan persaingan usaha di sektor ini semakin meningkat. Untuk menjamin keberlangsungan perusahaan dan dapat berkompetisi dengan optimal dengan memiliki keunggulan kompetitif, maka perusahaan di sektor manufaktur harus dapat mengelola seluruh aktiva yang dimiliki dan kewajiban-kewajibannya semaksimal mungkin sehingga kegiatan operasional perusahaan dapat berjalan untuk mencapai tujuan perusahaan. Keberhasilan dalam mencapai tujuan perusahaan tersebut merupakan sebuah prestasi manajemen, yang dapat dipakai sebagai dasar pengambilan keputusan yang dapat diandalkan baik pihak internal maupun eksternal.

Kinerja perusahaan merupakan suatu gambaran tentang kondisi keuangan suatu perusahaan yang dianalisis dengan alat-alat analisis keuangan sehingga dapat diketahui mengenai baik buruknya keadaan keuangan suatu perusahaan yang mencerminkan kinerja perusahaan dalam periode tertentu. Hal ini sangat penting agar sumber daya digunakan secara optimal dalam menghadapi perubahan lingkungan. Kinerja keuangan merupakan prestasi kerja yang telah dicapai oleh perusahaan dalam suatu periode tertentu dan berkaitan erat dengan pengukuran dan penilaian kinerja suatu perusahaan. Selain dituntut untuk fokus pada perbaikan dan peningkatan kondisi internal seperti kinerja keuangan, namun perusahaan juga dituntut untuk mampu mengembangkan hubungan terhadap pihak internal maupun eksternal sebagai bentuk tanggung jawab sosial perusahaan kepada stakeholders internal maupun eksternal yang kemudian dikenal sebagai tanggung jawab sosial perusahaan atau Corporate Social Responsibility.

Praktik Corporate Social Responsibility (CSR) dalam hubungannya dengan pemangku kepentingan dapat dipahami dari perspektif Legitimacy Theory. Ketika terdapat kesenjangan antara ekspektasi masyarakat dan perilaku sosial perusahaan, maka akan muncul masalah legitimasi. Menurut Haniffa et al. (2005) jika terjadi ketidakselarasan antara sistem nilai perusahaan dan sistem nilai masyarakat, maka perusahaan akan kehilangan legitimasinya dan selanjutnya akan mengancam kelangsungan hidup perusahaan. Oleh karena itu, agar organisasi mendapatkan legitimasi beroperasi maka perlu memadukan antara kinerja perusahaan dengan ekspektasi atau persepsi publik, dan CSR menjadi salah satu cara untuk memenuhi harapan publik. Apabila perusahaan memiliki kinerja sosial dan lingkungan yang baik, maka akan memberikan keyakinan kepada para pemangku kepentingan terhadap kemampuan perusahaan dalam mengelola risiko sosial dan lingkungan dalam menjalankan bisnisnya.

Corporate Social Responsibility merupakan wujud pelaksanaan tanggungjawab sosial perusahaan kepada masyarakat. The World Business Council for Sustainable Development mendefinisikan CSR sebagai komitmen berkelanjutan dunia usaha untuk berperilaku etis dan berkontribusi terhadap pembangunan ekonomi sekaligus meningkatkan kualitas hidup tenaga kerja dan keluarganya, serta komunitas lokal dan masyarakat luas pada umumnya. Di Indonesia, praktik CSR semakin menguat terutama setelah diberlakukan UU No. 40 Tahun 2007 tentang Perseroan Terbatas pasal 1 poin 3 yang menyebutkan bahwa PT. yang menjalankan usaha di bidang dan atau bersangkutan dengan sumber daya alam wajib menjalankan tanggungjawab sosial dan lingkungan. Selain itu Peraturan Pemerintah Nomor 47 Tahun 2012 tentang tanggungjawab sosial dan 
lingkungan sebagai upaya melaksanakan ketentuan Pasal 74 Undang-Undang Nomor 40 Tahun 2007. Peraturan Pemerintah Nomor 47 Tahun 2012 ini menegaskan bahwa perseroan yang kegiatan usahanya di bidang dan/atau berkaitan dengan sumber daya alam diwajibkan untuk melaksanakan tanggung jawab sosial dan lingkungan. Saat ini CSR telah dijadikan sebagai salah satu strategi oleh perusahaan untuk meningkatkan citra perusahaan yang akan mempengaruhi kinerja keuangan perusahaan.

Berkembangnya praktik CSR oleh tidak terlepas dari motivasi perusahaan dalam mengimplementasikannya. Ghozali dan Chariri (2007) mengidentifikasi alasan yang mendorong praktik pengungkapan tanggung jawab sosial dan lingkungan antara lain seperti : (a) mematuhi persyaratan yang ada dalam Undang-undang; (b) pertimbangan rasionalitas ekonomi; (c) mematuhi pelaporan dan proses akuntabilitas; (d) mematuhi persyaratan peminjaman; (d) mematuhi harapan masyarakat; (e) konsekuensi ancaman atas legitimasi perusahaan; (f) mengelola kelompok stakeholder tertentu; (g) menarik dana investasi; (h) mematuhi persyaratan industri serta (i) memenangkan penghargaan pelaporan. Namun demikian adanya praktik manajemen laba dapat merusak kepentingan dari stakeholder ketika manajer opportunistik melakukan manipulasi pendapatan dengan menggunakan CSR sebagai cara yang powerful dalam memenuhi harapan stakeholders (Prior, Surroca dan Tribo, 2008).

Manajemen laba dapat dipahami dalam dua perspektif yaitu oportunistic earnings management dan efficient earnings management (Rahmawati, 2006). Perilaku oportunistik manajer dalam melakukan manajemen laba bertujuan untuk memaksimumkan utilitasnya dalam menghadapi kontrak kompensasi, kontrak utang dan political costs. Dari perspektif efficient contracting manajemen laba memberi manajer suatu fleksibilitas untuk melindungi diri mereka dan perusahaan dalam mengantisipasi kejadian-kejadian yang tak terduga untuk keuntungan pihak-pihak yang terlibat dalam kontrak. Roychowdhury (2006) menjelaskan bahwa manajemen laba dapat dilakukan melalui manajemen laba akrual dan manajemen laba rill. Manajemen laba yang dilakukan dengan discretionary accrual yang tidak memiliki pengaruh terhadap arus kas secara langsung yang disebut dengan manajemen laba akrual. Manajemen laba akrual dilakukan pada akhir periode ketika manajer mengetahui laba sebelum direkayasa sehingga dapat mengetahui berapa besar manipulasi yang diperlukan agar target laba tercapai. Manajemen laba riil (real earnings manipulation) dapat terjadi sepanjang periode akuntansi. Kegiatan manajemen laba riil dimulai dari praktik operasional yang normal, yang dimotivasi oleh manajer yang berkeinginan untuk menyesuaikan beberapa akun penjualan dan biaya produksi agar beberapa stakeholder untuk percaya bahwa tujuan pelaporan keuangan tertentu telah dipenuhi dalam operasi normal perusahaan (Koyuimirsa dan Rahardja, 2011).

Dengan demikian fokus penelitian ini adalah untuk menguji secara empiris adanya keterkaitan manajer untuk menggunakan mekanisme CSR sebagai alat yang ampuh untuk pertahanan diri ketika melakukan tindakan yang merusak kepentingan stakeholder. Cespa dan Cestone (2007) menjelaskan bahwa manajemen yang memanipulasi laba mempunyai insentif untuk memproyeksikan socially-friendly image melalui aktivitas CSR untuk memperoleh dukungan dari stakeholder. Dengan strategi tersebut, manager akan mengurangi kemungkinan mendapat tekanan akibat ketidakpuasan stakeholder yang kepentingannya dirusak dengan adanya praktik manajemen laba. Penelitian ini 
memberikan kontribusi kebijakan tentang perlunya regulasi yang mengatur tentang ketentuan pelaporan CSR dan evaluasi terhadap praktik CSR perusahaan. Dengan demikian CSR perusahaan benar-benar dapat berkontribusi untuk peningkatan kinerja perusahaan dalam jangka panjang serta kesejahteraan stakeholder, dan bukan hanya motif oportunistik untuk kepentingan jangka pendek.

\section{Kerangka Teoretis Dan Pengembangan Hipotesis}

Legitimacy theory mengargumentasikan bahwa perusahaan memiliki kontrak dengan masyarakat untuk melakukan kegiatannya berdasarkan nilai-nilai keadilan, dan bagaimana perusahaan menanggapi berbagai kelompok kepentingan untuk melegitimasi tindakan perusahaan (Haniffa et al., 2005). Dengan demikian keberlangsungan hidup suatu perusahaan tergantung dari hubungan perusahaan dengan masyarakat dan lingkungan dimana perusahaan tersebut menjalankan setiap aktivitasnya. Fokus perusahaan tidak hanya untuk memenuhi harapan kelompok stakeholder tertentu seperti pemegang saham, namun juga kepentingan stakholder lainnya yang mempunyai kepentingan berbeda. Dalam kaitannya dengan praktik CSR oleh perusahaan, perusahaan harus dapat memenuhi norma dan harapan masyarakat agar dapat menjaga eksistensinya. Keterlibatan perusahaan dalam aktivitas tanggung jawab sosial perusahaan dapat menjadi cara untuk menjaga hubungan perusahaan dengan para pemangku kepentingan (stakeholder-relation). Perspektif stakeholders theory menyatakan bahwa perusahaan bukanlah suatu entitas yang hanya beroperasi untuk kepentingannya sendiri, namun harus memberikan manfaat bagi stakeholder-nya seperti pemegang saham, kreditor, konsumen, supplier, pemerintah, dan masyarakat, analis, dan pihak lain. Para stakeholder dengan kepentingan yang beragam membutuhkan berbagai informasi terkait dengan aktivitas perusahaan yang digunakan dalam pengambilan keputusan. Oleh karena itu, perusahaan akan berusaha untuk memberikan berbagai informasi yang dimiliki untuk menarik dan mencari dukungan dari para stakeholder-nya.

Kegiatan dalam memenuhi kewajiban tanggung jawab sosial dan lingkungan tersebut harus dianggarkan dan diperhitungkan sebagai biaya perseroan yang dilaksanakan dengan memperhatikan kepatutan dan kewajaran. Dalam aspek pelaporan aktivitas CSR, Global Reporting Initiative (GRI) digunakan sebagai acuan bagi sebagian besar perusahaan di Indonesia dalam melakukan pelaporan aktivitas tanggung jawab sosial perusahaan. GRI merupakan sebuah organisasi non-profit yang mempromosikan keberlanjutan ekonomi. Pedoman yang digunakan dalam pengungkapan Corporate Social Responsibility saat ini sudah mengeluarkan standar terbaru yaitu Global Reporting Initiative Standard (GRI Standard). GRI Standard diperkenalkan menjelang kuartal keempat tahun 2016 kemudian diluncurkan di Indonesia pada tahun 2017. Standar ini mulai berlaku untuk laporan atau materi lain yang dipublikasikan pada atau setelah 1 Juli 2018. GRI standar merupakan pengembangan pedoman pengungkapan Corporate Social Responsibility terdahulu yaitu GRI G4, G3, dan G3.1. Berdasarkan Global Reporting Initiative (GRI) Standard pengungkapan Corporate Social Responsibiliity meliputi 3 topik spesifik. Topik spesfik yaitu pengungkapan dimensi ekonomi, pengungkapan dimensi lingkungan, dan pengungkapan dimensi sosial, pengungkapan dimensi ekonomi menghasilkan 13 item penilaian, pengungkapan dimensi lingkungan menghasilkan 30 item penilaian dan 
pengungkapan dimensi sosial menghasilkan 34 penilaian. Secara keseluruhan terdapat 77 item penilaian Corporate Social Responsibility berdasarkan GRI standard.

Kinerja keuangan merupakan prestasi kerja yang telah dicapai oleh perusahaan dalam suatu periode tertentu dan dinyatakan dalam laporan keuangan perusahaan. Kinerja perusahaan dapat diketahui dari pengukuran berbagai rasio keuangan. Kinerja keuangan dari suatu perusahaan yang telah dicapai dalam satu tahun atau satu periode waktu adalah gambaran sehat atau tidaknya keadaan suatu perusahaan. Menurut Fidhayatin (2012:205) perusahaan yang sehat akan dapat memberikan laba bagi para pemilik modal, dan dapat membayar hutang dengan tepat waktu. Salah satu rasio yang penting untuk menilai kinerja perusahaan adalah rasio profitabilitas yang sering menjadi daya tarik bagi investor dalam menilai perusahaan dalam berinvestasi.

Dalam upaya mencapai kinerja perusahaan, pihak manajemen perusahaan memiliki fleksibilitas yang tingi untuk mengatur pola pelaporan laba melalui earnings management. Rahmawati (2006) menyatakan bahwa manajemen laba merupakan pemilihan kebijakan akuntansi oleh manajer dari standar akuntansi yang ada dan secara alami dapat memaksimumkan utilitas mereka atau nilai pasar perusahaan. Meskipun pada prinsipnya manajemen laba tidak menyalahi prinsip akuntansi yang berterima umum, namun manajemen laba dinilai dapat menurunkan kepercayaan masyarakat terhadap perusahaan, menurunkan nilai laporan keuangan dan memberikan informasi yang tidak relevan bagi investor. Dengan menurunnya kepercayaan masyarakat akan berdampak pada menurunnya nilai perusahaan karena banyak investor yang akan menarik kembali investasi yang telah ditanamkan.

\section{Pengembangan Hipotesis}

Dengan adanya tuntutan terhadap tanggung jawab sosial perusahaan, manajer berkeinginan untuk perusahaan mendapatkan legitimasi dari masyarakat. Sesuai dengan teori Legitimasi yang menegaskan bahwa perusahaan terus berupaya untuk memastikan bahwa mereka beroperasi dalam bingkai dan norma yang ada dalam masyarakat atau lingkungan dimana perusahaan berada. Selain alasan legitimasi, aktivitas CSR sangat membantu dalam membangun sebuah citra positif diantara para stakeholder (Orlitzky, Schmidt dan Rynes, 2003). Citra positif ini dapat meningkatkan reputasi perusahaan di pasar modal karena dapat meningkatkan kemampuan mereka dalam menegosiasikan kontrak yang menarik dengan suppliers dan pemerintah, menetapkan premium prices terhadap barang dan jasa, dan mengurangi biaya modal sehingga perusahaan mendapatkan peraturan pemerintah yang lebih menguntungkan serta pengawasan yang tidak terlalu ketat dari investor dan karyawan. Berkaitan dengan pengungkapan kinerja perusahaan, studi Ajilaksana (2011) menemukan bahwa semakin baik perusahaan melakukan pengungkapan tanggung jawab sosial perusahaan maka investor akan mengetahui informasi tentang kepedulian perusahaan terkait dengan lingkungan maka perusahaan bersedia menambah investasinya sehingga membuat nilai pasar perusahaan menjadi lebih baik. Aprilia dkk (2011) menemukan bahwa CSR berpengaruh negatif signifikan terhadap kinerja keuangan dan nilai perusahaan pada perusahaan multinasional di Indonesia serta berpengaruh positif signifikan terhadap kinerja keuangan dan nilai perusahaan pada perusahaan multinasional di Malaysia. 
Studi lainnya dilakukan oleh Rafianto (2014) pada perusahan pertambangan terdaftar di BEI tahun 2010-2012 mengungkapkan bahwa pengungkapan CSR berpengaruh terhadap kinerja keuangan. Hasil dari penelitian ini menemukan bahwa pengungkapan tanggung jawab sosial perusahaan tidak berpengaruh positif dan signifikan terhadap pertumbuhan penjualan. Di sisi lain, pengungkapan tanggung jawab sosial perusahaan memiliki efek positif dan signifikan terhadap pengembalian aset. Penelitian berbeda dilakukan oleh Martin dkk (2018) yang mengungkapkan bahwa pengungkapan tanggung jawab sosial perusahaan tidak berpengaruh positif terhadap pertumbuhan penjualan, namun memiliki efek positif dan signifikan terhadap pengembalian aset. Dengan demikian keterlibatan perusahaan dalam aktivitas yang berkaitan dengan tanggung jawab lingkungan akan berdampak terhadap pencapaian kinerja keuangan, sehingga dapat dirumuskan hipotesis sebagai berikut:

$\mathrm{H}_{1}$ : Pengungkapan CSR berpengaruh terhadap kinerja keuangan perusahan.

Teori stakeholder menyatakan bahwa hubungan yang positif dengan stakeholder kunci (key-shareholder) yang akan dapat meningkatkan kinerja keuangan dapat dicapai dengan adanya manajemen yang baik (Donaldson dan Preston, 1995). Teori stakeholder mengargumnetasikan bahwa CSR yang dapat digunakan sebagai alat organisasi untuk menggunakan sumber daya yang lebih efektif yang mempunyai dampak positif terhadap kinerja keuangan perusahaan. Oleh karena itu, intangible asset yang berupa strategi manajemen atas hubungan dengan stakeholder dapat dipandang sebagai suatu alat yang dapat memperbaiki kinerja keuangan dengan menggunakan sumber daya berdasarkan teori perusahaan (Hillman dan Keim, 2001).

Tingkat manajemen laba mempengaruhi hubungan antara CSR dan profitabilitas. Namun demikian, dampak positif dari CSR terhadap kinerja keuangan perusahaan berkurang secara signifikan karena ketika perusahaan melakukan aktivitas CSR sebagai suatu konsekuensi dari manajemen laba. Aktivitas CSR yang cenderung dilakukan dalam bentuk investasi yang berlebihan (over-invest) dapat menjadi salah satu strategi pertahanan diri bagi manajer. CSR dapat menjadi hal yang tidak produktif dan boros, sehingga mempunyai dampak marginal negatif terhadap kinerja keuangan (Rahmawati dan Dianita, 2011), ketika manajer yang melakukan manajemen laba berusaha untuk melibatkan pihak stakeholder sebagai salah satu cara untuk memvalidasi tindakannya agar tidak mendapat tekanan stakeholder lainnya. Tindakan tersebut bertujuan untuk mengurangi fleksibilitas organisasi dan berpengaruh terhadap hasil keuangan yang merugikan. Kusuma \& Syarifuddin (2014) dalam penelitiannya menemukan bahwa semakin tinggi tingkat manajemen laba, maka CSR berpengaruh negatif terhadap kinerja keuangan perusahaan di masa depan. Studi yang sejalan dikemukakan oleh Kusuma (2013) yang menemukan bahwa manajemen laba dapat memoderasi hubungan antara CSR dan kinerja keuangan perusahaan dan menunjukkan pengaruh yang negatif signifikan. Berdasarkan uraian di atas dapat dirumuskan hipotesis sebagai berikut adalah:

$\mathrm{H}_{2}$ : manajemen laba memoderasi pengungkapan CSR dan kinerja keuangan 


\section{Metode Penelitian}

Jenis penelitian yang digunakan dalam penelitian ini adalah explanatory research dengan pendekatan kuantitatif. Populasi dalam penelitian ini adalah seluruh perusahaan manufaktur yang terdaftar di Bursa Efek Indonesia (BEI) periode 2016-2018. Sampel penelitian sebanyak 113 perusahaan manufaktur yang melakukan pengungkapan CSR secara konsisten dalam periode amatan.

Variabel dependen penelitian ini adalah kinerja keuangan, dan pengungkapan CSR adalah variabel independen, sedangkan manajemen laba adalah variabel pemoderasi. Dalam hal ini manajemen laba diproksikan menggunakan dua pengukuran yaitu manajemen laba akrual dan manajemen laba rill. Pengukuran variabel dinyatakan sebagai berikut :

a. Kinerja keuangan adalah suatu analisis yang dilakukan untuk melihat sejauh mana suatu perusahan telah menggunakan aturan-aturan pelaksanaan keuangan dengan baik dan benar (Pongoh, 2013). Dalam penelitian ini rasio kinerja keuangan yang digunakan adalah rasio profitbilitas yang di proksikan menggunakan Return On Assets (ROA) dengan membagi laba setelah pajak dengan total aset yang dimiliki perusahaan.

b. Pengungkapan Corporate Social Responsibility dalam penelitian ini diukur dengan menggunakan indikator dalam Global Reporting Initiative/ GRI Standar yang meliputi 3 topik spesifik yaitu dimensi ekonomi, lingkungan, dan sosial. Perhitungan indeks pengungkapan CSR (CSR) dilakukan dengan memberikan skor 1 jika suatu item diungkapkan, dan 0 jika tidak diungkapkan.

c. Manajemen Laba dalam penelitian ini diproksikan dengan menggunakan manajemen laba akrual dan manajemen laba riil.

- Manajemen laba akrual. Akrual adalah selisih antara kas masuk bersih dari hasil operasi perusahaan dengan laba yang dilaporkan dalam laporan laba rugi, yang bersifat discretionary accruals dan non discretionary accruals. Manajemen laba akrual diproksikan dengan discretionary accruals yang dihitung dengan menggunakan The Jones Modified Model sebagai berikut :

$$
\begin{aligned}
& \mathrm{TACC}_{\text {it }}=\mathrm{EXBT}_{\text {it }}-\mathrm{OCF}_{\text {it }}
\end{aligned}
$$

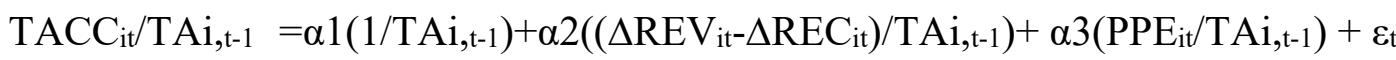

$$
\begin{aligned}
& \mathrm{NDACC}_{\mathrm{it}} \quad=\alpha 1\left(1 / \mathrm{TAi}_{, \mathrm{t}-1}\right)+\alpha 2\left(\left(\Delta \mathrm{REV}_{\mathrm{it}}-\Delta \mathrm{REC}_{\mathrm{it}}\right) / \mathrm{TAi}_{\mathrm{i}-\mathrm{t}-1)}\right)+\alpha 3\left(\mathrm{PPE}_{\mathrm{it}} / \mathrm{TAi}, \mathrm{t}-1\right) \\
& \mathrm{DACC}_{\mathrm{it}} \quad=\left(\mathrm{TACC}_{\mathrm{it}} / \mathrm{TAi}, \mathrm{t}-1\right)-\mathrm{NDACC}_{\mathrm{it}}
\end{aligned}
$$

Keterangan:

$$
\begin{array}{ll}
\mathrm{TACC}_{\mathrm{it}} & =\text { Total Accruals perusahaan i pada periode } \mathrm{t} \\
\mathrm{EXBT}_{\mathrm{it}} & =\text { Earning before Extraordinary Item perusahaan } \mathrm{i} \text { pada periode } \mathrm{t} \\
\mathrm{OCF}_{\mathrm{it}} & =\text { Operating Cash Flows perusahaan i padaperiode } \mathrm{t} \\
\mathrm{TAi}, \mathrm{t}-1 & =\text { Total assets perusahaan i pada periode } \mathrm{t}-1 \\
\Delta \mathrm{REV}_{\mathrm{it}} & =\text { Perubahan pendapatan perusahaan i pada periode } \mathrm{t} \\
\Delta \mathrm{REC}_{\mathrm{it}} & =\text { Perubahan piutang perusahaan i pada periode } \mathrm{t} \\
\mathrm{PPE}_{\mathrm{it}} & =\text { Property, Plan, dan Equipment perusahaan i pada periode } \mathrm{t} \\
\mathrm{DACC}_{\mathrm{it}} & =\text { Discretionary accruals perusahaan i pada periode } \mathrm{t} \\
\mathrm{NDACC}_{\mathrm{it}} & =\text { Non-discretionary accruals perusahaan i pada periode } \mathrm{t} . \\
\mathrm{e}_{\mathrm{t}} & =\text { error term }
\end{array}
$$


- Manajemen Laba Aktivitas Rill

Manajemen laba aktivitas riil merupakan manipulasi yang dilakukan oleh manajemen melalui aktivitas operasional perusahaan sehari-hari selama periode akuntansi. Dalam penelitian ini manajemen laba riil dihitung menggunakan arus kas operasi, dengan alasan karena laporan arus kas merupakan salah satu jenis laporan keuangan perusahaan yang perlu dicermati karena memiliki informasi yang tidak kalah penting dari laporan laba rugi. Dalam laporan arus kas terdapat laporan arus kas aktivitas operasi yang terdiri dari aktivitas-aktivitas operasional perusahaan. Model regresi untuk manajemen laba rill merujuk pada cara perhitungan yang dilakukan oleh Roychowdhury (2006) sebagai berikut :

$\mathrm{CFO}_{\mathrm{t}} / \mathrm{A}_{\mathrm{t}-1}=\alpha_{0}+\alpha 1\left(1 / \mathrm{At}_{\mathrm{t}-1}\right)+\beta 1\left(\mathrm{~S}_{\mathrm{t}} / \mathrm{A}_{\mathrm{t}-1}\right)+\beta 2\left(\Delta \mathrm{st}_{\mathrm{t}} / \mathrm{A}_{\mathrm{t}-1}\right)+\varepsilon \mathrm{t}$

Keterangan :

$\mathrm{CFO}=$ Arus kas operasi perusahaan i pada tahun $\mathrm{t}_{\mathrm{t}}$

$\mathrm{A}_{\mathrm{t}-1}=$ Total Aset perusahaan i pada tahun $\mathrm{t}-1$

$\mathrm{S}_{\mathrm{t}} \quad=$ Penjualan total perusahaan $\mathrm{i}_{\text {pada }}$ tahun $\mathrm{t}_{\mathrm{t}}$

Prosedur analisis data yang digunakan adalah menggunakan analisis statistik deskriptif dan uji asumsi klasik. Uji Asumsi klasik untuk memberikan kepastian bahwa persamaaan regresi yang didapatkan memiliki ketepatan dalam estimasi, tidak bias dan konsisten. Terdapat kemungkinan data aktual tidak memenuhi semua asumsi klasik sehingga dimungkinkan pengecekan kembali data outlier maupun recollector data dilakukan. Dalam penelitian ini menggunakan 4 pengujian yaitu uji normalitas, uji multikolinearitas, uji heteroskedastisitas, dan uji autokorelasi. Selanjutnya dilakukan analisis regresi linier sederhana (simple regression analysis) dan Moderated Regression Analysis (MRA) dengan persamaan matematis sebagai berikut :

Model $1: \mathrm{ROA}_{\mathrm{it}}=\lambda 1+\lambda 2(\mathrm{CSR})_{\mathrm{it}}+\dot{\varepsilon}_{\mathrm{it}}$

Model $2: \mathrm{ROA}_{\mathrm{it}}=\lambda 1+\lambda 2(\mathrm{CSR})_{\mathrm{it}}+\lambda 3(\mathrm{DA})_{\mathrm{it}}+\lambda 4\left[(\mathrm{CSR} * \mathrm{DA})_{\mathrm{it}}\right]+\dot{\varepsilon}_{\mathrm{it}}$

Model $3: \mathrm{ROA}_{\mathrm{it}}=\lambda 1+\lambda 2(\mathrm{CSR})_{\mathrm{it}}+\lambda 3(\mathrm{CFO})_{\mathrm{it}}+\lambda 4\left[(\mathrm{CSR} * \mathrm{CFO})_{\mathrm{it}}\right]+\dot{\varepsilon}_{\mathrm{it}}$

Keterangan:

ROA $=$ Variabel kinerja keuangan perusahaan

CSR $\quad=$ Variabel pengungkapan CSR

$\mathrm{DA} \quad=$ Variabel manajemen laba akrual

$\mathrm{CFO} \quad=$ Variabel manajemen laba rill

$\mathrm{CSR} * \mathrm{DA}=$ Variabel pemoderasi laba akrual

$\mathrm{CSR} * \mathrm{CFO}=$ Variabel pemoderasi laba rill

$\lambda 1=$ Konstanta

$\lambda 1, \lambda 2, \ldots . \lambda 4=$ Koefisien regresi

$\dot{\varepsilon}=$ error

\section{Hasil dan Pembahasan}

Objek penelitian ini merupakan perusahaan manufaktur yang terdaftar di Bursa Efek Indonesia selama 3 periode amatan yaitu tahun 2016-2018 dengan jumlah 162 
perusahaan yang terdaftar di Bursa Efek Indonesia. Dari 162 perusahaan tersebut, 113 perusahaan menjadi sampel setelah seleksi sampel berdasarkan teknik purposive sampling. Data berupa laporan keuangan dan laporan tahunan yang digunakan dalam penelitian ini diakses melalui website BEI dan website perusahaan. Berdasarkan metode purposive sampling, terdapat 113 perusahaan atau $70 \%$ yang menjadi sampel penelitian dengan periode pengamatan yang digunakan adalah 3 periode yaitu 2016-2018 sehingga diperoleh jumlah observasi sebanyak 339 sebagaimana disajikan pada tabel 1.

Tabel 1. Jumlah Sampel dan Sebarannya Berdasarkan Sektor Industri

\begin{tabular}{|c|c|c|c|c|}
\hline No & Sektor & Populasi & Sampel & $\%$ \\
\hline 1 & $\begin{array}{l}\text { Sektor Industry Dasar Dan Kimia } \\
\text { - Sub Sektor Semen } \\
\text { - Sub Sektor Keramik, Porselen Dan Kaca } \\
\text { - Sub Sektor Logam Dan Sejenisnya } \\
\text { - Sub Sektor Kimia } \\
\text { - Sub Sektor Plastic Dan Kemasan } \\
\text { - Sub Sektor Pakan Ternak } \\
\text { - Sub Sektor Industry Kayu } \\
\text { - Sub Sektor Bubur Kertas } \\
\text { - Sub Sektor Lainnya }\end{array}$ & $\begin{array}{c}6 \\
8 \\
15 \\
13 \\
12 \\
4 \\
2 \\
9 \\
1\end{array}$ & $\begin{array}{c}6 \\
5 \\
13 \\
8 \\
10 \\
3 \\
2 \\
8 \\
0\end{array}$ & $\begin{array}{c}100 \\
63 \\
87 \\
62 \\
83 \\
75 \\
100 \\
89 \\
0\end{array}$ \\
\hline 2 & $\begin{array}{l}\text { Sektor Aneka Industri } \\
\text { - Sub Sektor Mesin Dan Alat Berat } \\
\text { - Sub Sektor Otomotif Dan Komponen } \\
\text { - Sub Sektor Tekstil Dan Germen } \\
\text { - Sub Sektor Alas Kaki } \\
\text { - Sub Sektor Kabel } \\
\text { - Sub Sektor Elektronika }\end{array}$ & $\begin{array}{c}4 \\
13 \\
19 \\
2 \\
6 \\
2\end{array}$ & $\begin{array}{c}1 \\
10 \\
12 \\
2 \\
5 \\
1\end{array}$ & $\begin{array}{c}25 \\
77 \\
63 \\
100 \\
83 \\
50\end{array}$ \\
\hline 3 & $\begin{array}{l}\text { Sektor Industry Barang Konsumsi } \\
\text { - Sub Setor Makanan Dan Minuman } \\
\text { - Sub Setor Pabrik Tembakau } \\
\text { - Sub sektor farmasi } \\
\text { - Sub sektor kosmetik \& barang keperluan rumah tangga } \\
\text { - Sub sektor peralatan rumah tangga } \\
\text { - Sub sektor lainnya }\end{array}$ & $\begin{array}{c}20 \\
4 \\
10 \\
7 \\
4 \\
1 \\
\end{array}$ & $\begin{array}{l}9 \\
4 \\
7 \\
5 \\
2 \\
0\end{array}$ & $\begin{array}{c}45 \\
100 \\
70 \\
71 \\
50 \\
0 \\
\end{array}$ \\
\hline & Jumlah & 162 & 113 & 70 \\
\hline
\end{tabular}

Hasil Pengujian statistik despkriptif disajikan pada tabel 2. Pengungkapan CSR perusahaan berdasarkan GRI Standard lebih banyak berkaitan dengan dimensi lingkungan dibandingkan dengan dimensi ekonomi dan sosial. Pengungkapan dimensi ekonomi masih tergolong rendah dengan persentase sebesar 3,11\%. Rata-rata pengungkapan dimensi lingkungan adalah 0,0791 dan Standar deviasi variabel dimensi lingkungan dari jumlah observasi sebesar 0,09747 . Hal ini berarti penyebaran dan variasi data semakin luas $(0,09747>0,0791)$. Rata-rata pengungkapan dimensi sosial 0,0601 atau sebesar 6\% masih relatif rendah. Rata-rata perolehan Return On Asset (ROA) sebesar 5,3652, dan standar deviasi sebesar 9,21131 serta nilai maksimum ROA sebesar 52,67 yang menunjukkan kemampuan perusahaan dalam mengelola asetnya untuk memperoleh laba sangat baik, namun demikian nilai minimum ROA sebesar -21,82 yang menggambarkan perolehan laba negatif. 
Rata-rata variabel manajemen laba akrual sebesar 0, 1463 dengan standar deviasi 0, 65476. Nilai maksimum manajemen laba akrual sebesar 9,69 dan nilai minimum manajemen laba akrual sebesar -1,08. Hal ini mengindikasikan bahwa rata-rata perusahaan melakukan pola pelaporan laba yang cenderung meningkat (income increasing), meskipun ada perusahaan yang melakukan income decreasing dengan nilai manajemen laba akrual negatif. Adapun rata-rata manajemen laba riil sebesar 0, 2691. Standar deviasi variabel manajemen laba riil dari jumlah observasi sebesar 0,58385 dengan nilai maksimum sebesar 5, 95 serta nilai minimum manajemen laba riil sebesar -0 , 32. Dalam hal ini rata-rata perusahaan cenderung melakukan pola pelaporan laba yang cenderung meningkat.

Tabel 2. Stastistik Deskriptif

\begin{tabular}{llrrrr}
\hline & N & Minimum & Maximum & \multicolumn{1}{c}{ Mean } & Std. Deviation \\
\hline Ekonomi & 339 & .00 & .61 & .0311 & .06172 \\
Lingkungan & 339 & .00 & .87 & .0791 & .09747 \\
Sosial & 339 & .01 & .46 & .0601 & .05578 \\
ROA & 339 & -21.82 & 52.67 & 5.7455 & 9.64913 \\
Akrual & 339 & -1.08 & 9.69 & .1463 & .65476 \\
Riil & 339 & -.32 & 5.95 & .2691 & .58385 \\
CSRxAkrual & 339 & -.30 & 1.96 & .0317 & .14591 \\
CSRxRiil & 339 & -.05 & 1.42 & .0493 & .12539 \\
Valid N (listwise) & 339 & & & & \\
\hline
\end{tabular}

Hasil pengujian asumsi klasik uji normalitas menunjukkan bahwa data tidak terdistribusi normal sehingga dilakukan transformasi data dan tindakan remedial, dengan cara melakukan check data outlier dan transformasi Square Root (SQRT) sehingga akhirnya data memiliki nilai residual yang terdistribusi normal dengan nilai Asymp. Sig. (2-tailed) lebih besar dari 0,05. Hasil perhitungan statistik untuk menguji adanya gejala multikolinieritas menunjukkan tidak ada variabel yang memiliki nilai tolerance kurang dari 0,10 yang berarti tidak ada korelasi antar variabel yang nilainya lebih dari $95 \%$. Sedangkan hasil perhitungan nilai Variance Inflation Factor (VIF) juga menunjukkan hal yang sama tidak ada variabel yang memiliki nilai VIF lebih dari 10 sehingga dapat dinyatakan bahwa tidak ada masalah multikolonieritas. Pada pengujian heteroskedastisitas dapat diketahui bahwa seluruh variabel memiliki nilai signifikan $>0,05$, ini berarti pada seluruh model regresi tidak terjadi gejala heteroskedastisitas. Nilai Durbin Watson (DW) untuk $\mathrm{N}=339$, dan $\mathrm{K}=3$ diperoleh $\mathrm{dl}=1,80724$ dan $\mathrm{du}=1,83162$. Nilai DW untuk model yang diuji memiliki DW diatas nilai batas atas (du) sehingga terjadi masalah autokorelasi. Langkah yang dapat digunakan untuk mengatasi masalah autokorelasi adalah menggunakan tranformasi cocharane orcutt. Hasil transformasi menunjukkan bahwa nilai DW lebih besar dari batas atas (du) yaitu 1,999 > 1,83162 dan kurang dari 4-dl sehingga dapat dinyatakan bahwa sudah tidak ada masalah autokorelasi sehingga pengujian selanjutnya dapat dilakukan.

Dalam penelitian ini pengujian regresi dilakukan melalui 3 tahapan, yang dinyatakan dalam 3 model regresi sebagaimana disajikan pada tabel 3. Model 1 menguji pengaruh pengungkapan CSR terhadap kinerja perusahaan, sedangkan model 2 dan model 3 menguji interaksi manajemen laba (akrual dan riil) dalam memoderasi pengaruh pengungkapan CSR terhadap kinerja keuangan. 
Tabel 3. Hasil Uji Hipotesis Moderate Regression Analysis (MRA)

\begin{tabular}{llccccccc}
\hline \multirow{2}{*}{ Model } & \multirow{2}{*}{ Variabel } & \multicolumn{2}{c}{ Uji F } & \multicolumn{2}{c}{ Koefisien Determinasi } & \multicolumn{3}{c}{ Uji t } \\
\cline { 3 - 8 } & & F & Sig. & R $^{2}$ & Adjusted R & Koefisien & t & Sig. \\
\hline Model 1 & Konstanta & 0,219 & $0,640(\mathrm{a})$ & 0,001 & -.003 & 0,899 & 6.306 & 0,000 \\
& CSR & & & & & 3,679 & 0,468 & 0,640 \\
\hline Model 2 & Konstanta & 15,758 & $0,000(\mathrm{a})$ & 0,133 & 0,125 & 0,874 & 5,638 & 0,000 \\
& CSR & & & & & 3,152 & -0.062 & 0,951 \\
& Akrual & & & & & 5,669 & $-0,735$ & 0,463 \\
& CSR*Akrual & & & & & 28,494 & 3,252 & $0,001^{*}$ \\
\hline Model 3 3 & Konstanta & 1,202 & $0,309(\mathrm{a})$ & 0,012 & 0,002 & 1,008 & 4.782 & 0,000 \\
& CSR & & & & & 3,876 & 0.826 & 0,410 \\
& Riil & & & & & 3,468 & 1.460 & 0,145 \\
& CSR*Riil & & & & & 18,767 & -0.755 & 0,451 \\
\hline
\end{tabular}

Hasil pengujian model 1 menunjukkan bahwa pengungkapan CSR berpengaruh positif tetapi tidak signifikan terhadap kinerja keuangan yang ditunjukkan oleh koefisien regresi sebesar 3,679 dan signifikansi 0,640 lebih besar dari 0,05. Uji F tidak signifikan yang ditunjukkan dengan nilai Ftest sebesar 0,219 dengan nilai signifikansi 0,640 lebih besar dari 0,05. Koefisien determinasi $\left(\mathrm{R}^{2}\right)$ model 1 menunjukkan nilai Adjusted $\mathrm{R}^{2}$ sebesar -0,003 atau sebesar -0,3\%. Jika dalam uji empiris didapat nilai adjusted $\mathrm{R}^{2}$ negatif, maka nilai adjusted $\mathrm{R}^{2}$ dianggap bernilai nol (Gujarati (2003) dalam Ghozali, 2005: 84).

Hasil pengujian moderasi pada model 2 menunjukkan bahwa manajemen laba yang diproksikan dengan discretionary accrual berpengaruh dalam memoderasi hubungan pengungkapan CSR dan kinerja keuangan dengan nilai signifikansi adalah 0,000 lebih kecil dari 5\%. Model 2 juga mengungkapkan bahwa pengungkapan CSR tidak berpengaruh negatif tidak signifikan terhadap kinerja keuangan, sedangkan manajemen laba akrual berpengaruh negatif namun tidak signifikan terhadap kinerja keuangan. Uji $F$ signifikan pada model 2 dengan koefisien determinasi memiliki nilai adjusted $R$ square sebesar 0,125 atau 12,5\%. Pengujian pada model 3 menggunakan proksi manajemen laba riil menunjukkan uji $\mathrm{F}$ yang tidak signifikan dengan koefisien determinasi yang sangat kecil sebesar 0,002. Hasil pengujian terhadap parameter individual juga menunjukkan hasil yang tidak signifikan baik untuk uji parsial pengungkapan CSR dan manajemen laba riil maupun pengujian interaksi terhadap kinerja keuangan.

Berdasarkan hasil analisis pada uji regresi dan MRA dapat diketahui bahwa hipotesis yang menguji pengaruh pengungkapan CSR terhadap kinerja keuangan memiliki arah hubungan positif dan tidak signifikan sehingga hipotesis 1 ditolak. Arah positif berarti ada hubungan yang searah antara pengungkapan CSR terhadap kinerja keuangan perusahaan yang di proksikan dengan ROA. Namun penelitian tidak berhasil membuktikan bahwa pengungkapan CSR akan berdampak signifikan terhadap kinerja keuangan. Penelitian ini sejalan dengan penelitian yang dilakukan oleh Mahrani \& Noorlailie (2018) yang menyatakan bahwa pengungkapan CSR tidak mempengaruhi kinerja keuangan. Hasil penelitian ini juga sejalan dengan studi Rafianto (2014) bahwa kinerja lingkungan tidak berpengaruh terhadap kinerja keuangan maupun studi Kusuma \& Syarifuddin (2014) yang menyatakan bahwa pengungkapan CSR memiliki pengaruh tidak signifikan terhadap kinerja keuangan. Hasil ini juga sejalan dengan studi Martin dkk (2018) yang menyatakan bahwa pengungkapan tanggung jawab sosial berpengaruh tidak signifikan terhadap kinerja keuangan, yang diukur menggunakan pertumbuhan penjualan dan tingkat pengembalian aset. Namun demikian hasil penelitian ini tidak sejalan hasil 
penelitian Aprilia dkk (2016) yang menyatakan bahwa CSR memiliki pengaruh signifikan negatif terhadap kinerja keuangan perusahaan maupun studi Martin dkk (2018) yang mnyatakan bahwa pengungkapan tanggung jawab sosial memiliki pengaruh negatif terhadap kinerja keuangan yang diukur menggunakan pertumbuhan penjualan.

Hipotesis kedua yang menguji interaksi manajemen laba dalam hubungan antara pengungkapan CSR dan kinerja keuangan menunjukkan hasil yang berbeda. Ketika proksi manajemen laba menggunakan akrual diskresioner maka manajemen laba memoderasi secara positif pengaruh pengungkapan CSR terhadap kinerja keuangan. Namun demikian ketika proksi manajemen laba menggunakan manipulasi aktivitas riil menunjukkan pengaruh moderasi yang tidak signifikan. Temuan penelitian ini mengindikasikan bahwa perusahaan yang melakukan manajemen laba akrual terbukti meningkatkan aktivitas CSR sebagai entrenchment stategy. Oleh karena itu, tingkat manajemen laba memperkuat hubungan antara CSR dan kinerja keuangan perusahaan yang diproksikan dengan Return On Asset (ROA). Berkaitan dengan proksi manajemen laba riil, hasil penelitian ini memberikan bukti bahwa manajemen yang melakukan manajemen laba rill tidak terbukti meningkatkan program CSR sebagai upaya pertahanan diri manajemen untuk menutupi praktik manajemen labanya dari sorotan stakeholder terhadap penilaian kinerja keuangan perusahaan. Temuan penelitian ini mengindikasikan bahwa akrual diskresioner lebih menjadi pilihan bagi manajer dalam melakukan manajemen laba dibandingkan menggunakan manipulasi aktivitas riil. Dengan demikian hasil ini tidak sejalan dengan penelitian yang dilakukan oleh Rahmawati dan Dianita (2011) serta Kusuma \& Syarifuddin (2014) yang menyatakan bahwa semakin tinggi tingkat manajemen laba maka CSR berpengaruh negatif terhadap kinerja keuangan perusahaan dimasa depan karena program CSR tersebut digunakan oleh manajemen sebagai salah bentuk entrenchement strategy untuk menutupi praktik manajemen laba yang dapat merusak kepentingan stakeholder.

Hasil penelitian ini mendukung Stakeholder Theory dan Legitimasi Theory. Stakeholders Theory mengatakan bahwa perusahaan bukanlah suatu entitas yang hanya beroperasi untuk kepentingannya sendiri, namun harus memberikan manfaat bagi stakeholder-nya seperti pemegang saham, kreditor, konsumen, supplier, pemerintah, masyarakat, analis, dan pihak lain. Para stakeholder membutuhkan berbagai informasi terkait dengan aktivitas perusahaan yang digunakan dalam pengambilan keputusan. Oleh karena itu, perusahaan akan berusaha untuk memberikan berbagai informasi yang dimiliki untuk menarik dan mencari dukungan dari para stakeholder-nya. Hasil penelitian memberikan implikasi teoretis terhadap Legitimacy Theory yang dapat memberikan pemahaman mengenai kesadaran perusahaan akan pentingnya suatu pengungkapan tanggung jawab sosial perusahaan sebagai upaya untuk menjamin eksistensi perusahaan dengan cara memenuhi harapan dari masyarakat dan lingkungan. Dalam aspek praktis, hasil penelitian ini diharapkan dapat digunakan sebagai bahan pertimbangan dalam melakukan perbaikan maupun peningkatan kinerja perusahaan. Bagi investor, hasil penelitian ini diharapkan dapat memberikan informasi yang bermanfaat bagi investor untuk memudahkan dalam melakukan pengambilan keputusan investasi. Selanjutnya bagi masyarakat menjadi lebih peduli terhadap kegiatan dalam Corporate Social Responsibility yang dilakukan perusahaan. 


\section{Kesimpulan, Implikasi dan Keterbatasan}

Hasil penelitian ini menyatakan bahwa pengungkapan tanggung jawab sosial perusahaan berpengaruh positif namun tidak signifikan terhadap kinerja keuangan yang diukur dengan tingkat pengembalian aset. Meskipun memiliki arah hubungan positif, tetapi tidak signifikannya hasil pengujian diprediksi karena CSR merupakan kebijakan jangka panjang yang kinerjanya tidak dapat diukur dalam jangka pendek sehingga tidak signifikan mempengaruhi kinerja keuangan perusahaan. Namun demikian hasil pengujian moderasi menunjukkan bahwa interaksi manajemen laba akrual berpengaruh signifikan positif dalam memoderasi pengaruh pengungkapan CSR terhadap kinerja keuangan, meskipun menunjukkan hasil yang berlawanan ketika interaksi menggunakan manajemen laba riil. Hasil penelitian ini mengindikasikan bahwa perusahaan yang melakukan manajemen laba akrual terbukti meningkatkan aktivitas CSR sebagai entrenchment stategy untuk menutupi praktik manajemen laba yang dapat berpotensi merusak kepentingan stakeholder.

Penelitian ini memiliki beberapa keterbatasan yang dapat ditindaklanjuti dalam penelitian mendatang. Data penelitian terkait pengungkapan CSR perusahaan relatif terbatas dikarenakan tidak semua perusahaan manufaktur yang terdaftar di Bursa Efek Indonesia (BEI) mengungkapkan pelaporan CSR. Penelitian mendatang dapat menggunakan media pelaporan tanggungjawab sosial perusahaan lainnya seperti melalui website korporasi maupun laporan CSR tersendiri. Penelitian selanjutnya dapat memperluas analisis pada sektor lainnya dan menggunakan proksi kinerja keuangan lainnya, karena dimungkinkan ada perbedaan dalam praktik CSR dan pengukuran kinerja keuangan setiap sektor. Pengujian dengan perbedaan waktu (lag) dapat ditindaklanjuti pada penelitian mendatang karena kebijakan CSR sebagai suatu kebijakan jangka panjang yang dampaknya tidak dapat diukur dalam jangka pendek.

\section{Referensi}

Aprilia, Sari Wahyu, Siti Ragil Handayani, Nila Firdausi Nuzula. 2016. Pengaruh Pengungkapan Corporate Social Responsibility Terhadap Kinerja Keuangan Dan Nilai Perusahaan (Studi Komparatif Pada Perusahaan Multinasional Yang Terdaftar Di Bursa Efek Indonesia Dan Bursa Malaysia Tahun 2012-2015). Jurnal Administrasi Bisnis 39.(2), 74-83.

Cespa, G. \& Cestone, G. 2007. Corporate Social Responsibility and Resource-Based Perspectives. Journal of Business Ethics, 69, 111-32.

Rahmawati, P.S \& Rahmawati. 2011. Analysis of the Effect of Corporate Social Responsibility on Financial Performance With Earnings Management as a Moderating Variable. Journal of Modern Accounting and Auditing, 10 (7), 10341045.

Donaldson, Thomas, \& Lee E. Preston. 1995. The Stakeholder Theory of the Corporation: Concepts, Evidence, and Implications. The Academy of Management Review. 20 (1), 65-91. 
Fidhayatin, Septi Kurnia. 2012. Analisis Nilai Perusahaan, Kinerja Perusahaan Dan Kesempatan Bertumbuh Perusahaan Terhadap Return Saham Pada Perusahaan Manufaktur Yang Listing di BEI. Jurnal Akuntansi, 2 (2), 203-214.

Ghozali, imam. 2005. Aplikasi Analisis Multivariat dengan Program SPSS. Semarang: Badan Penerbit Universitas Diponegoro.

Ghozali, Imam dan Anis Chariri. 2007.Teori Akuntansi. Edisi Ketiga. Semarang: Badan Penerbit Universitas Diponegoro

Haniffa, R.M., dan T.E. Cooke. 2005. The Impact of Culture and Governance on Corporate Social Reporting. Journal of Accounting and Public Policy 24 (5), 391-430.

Hilman, A. \& Keim, G. 2001. Shareholder value, stakeholder management, and social issues : Strategic Management Journal, 22 (2), 125-139.

Kusuma, Destia, Muchamad Syafruddin. 2014. Analisis Pengaruh Corporate Social Responsibility Terhadap Kinerja Keuangan Perusahaan Dengan Manajemen Laba Sebagai Variabel Pemoderasi .Diponegoro Journal Of Accounting, 3 (1), 1-13.

Kusuma, Destia. 2013. Analisis Pengaruh Corporate Social Responsibility TerhadapKinerja Keuangan Perusahaan Dengan Manajemen LabaSebagai Variabel Pemoderasi (Studi Empiris Pada Perusahan Partisipan Indonesian Sustainability Reporting Award Tahun 2009 - 2011). Fakultas Ekonomika Dan Bisnis Universitas Diponegoro Semarang.

Koyuimirsa \& S.Rahardja. 2011. Dampak Manajemen Laba Akrual dan Manajemen Laba Riil Terhadap Kinerja Pasar. Skripsi Universitas Diponegoro

Mahrani, M. \& Noorlailie Soewarno. 2018. The Effect of Good Governance Mechanism and Corporate Social Responsiility on financial Perfomance with Earning Management as mediating variable. Asian Journal of Accounting Research 3 (1), $41-60$

Martin, Winwin Yadiati, Arie Pratama. 2018. CSR Disclosure and Company Financial perfomance: Do High and Low Profile Industry Moderate the Result?. Indonesian Journal of Sustainability Accounting and Management, 2 (1), 15-24

Orlitzky, M., Schmidt, F. L. and Rynes, S. L. 2003. Corporate Social and Financial Performance: A meta-analysis. Journal of Organization Studies, 24 (3), 430-468.

Pongoh, Marsel. 2013. Analisis laporan keuangan dalam menilai kinerja keuangan pada PT Bumi Resources Tbk. Universitas Sam Ratulangi Manado. Jurnal EMBA 1(3), 669679.

Peraturan Pemerintah (PP) Nomor 47 Tahun 2012 tentang tanggungjawab sosial dan lingkungan.

Prior, D., Surroca, J. \& Tribo, J. A., 2008. Are Socially Responsible Managers Really Ethical? Exploring the Relationship between Earnings Management and Corporate Social Responsibility. Corporate Governance: An International Review, 16 (3), $160-177$ 
Rafianto, Rizki Anshari. 2014. Pengaruh Pengungkapan Corporate Social Responsibility dan Kinerja Lingkungan Terhadap Kinerja keuangan (Studipada Sektor Pertambangan di Bursa Efek Indonesia pada Periode 2010-2012). e-Proceeding of Management, 2 (1), 497-522

Rahmawati, Hikmah. 2013. Pengaruh Good Corporate Governance (GCG) Terhadap Manajemen Laba Pada Perusahaan Perbankan. Accounting Analysis Journal 2 (1), $9-18$

Rahmawati \& Putri Septia Dianita. 2011. Analysis of the Effect of Corporate Social Responsibility on Financial Performance With Earnings Management as a Moderating Variable. Journal of Modern Accounting and Auditing, 7 (10), 10341045.

Roychowdhury, Sugata. 2006. Earnings Management through Real Activities Manipulation. Journal of Accounting and Economic, 42 (3), 335-370.

Undang-undang Republik Indonesia Nomor 40 Tahun 2007 Tentang Perseroan Terbatas

https://www.globalreporting.org. Diakses 10 Juli 2019.

https://www.wbcsd.org.World Business Council For Sustainability Development 